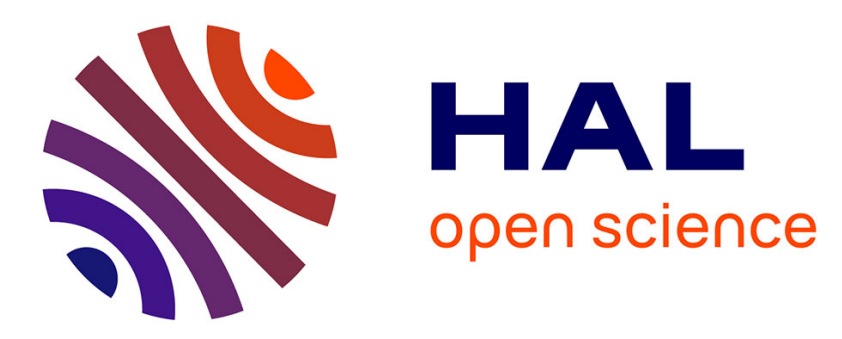

\title{
Reversal of Enantioselectivity in the Asymmetric Rhodium- versus Iridium-Catalyzed Hydroboration of Meso Substrates
}

\author{
Alejandro Pérez Luna, Martine Bonin, Laurent Micouin, Henri-Philippe
}

Husson

\section{To cite this version:}

Alejandro Pérez Luna, Martine Bonin, Laurent Micouin, Henri-Philippe Husson. Reversal of Enantioselectivity in the Asymmetric Rhodium- versus Iridium-Catalyzed Hydroboration of Meso Substrates. Journal of the American Chemical Society, 2002, 124 (41), pp.12098-12099. 10.1021/ja026714m . hal-02185596

\section{HAL Id: hal-02185596 \\ https://hal.science/hal-02185596}

Submitted on 16 Jul 2019

HAL is a multi-disciplinary open access archive for the deposit and dissemination of scientific research documents, whether they are published or not. The documents may come from teaching and research institutions in France or abroad, or from public or private research centers.
L'archive ouverte pluridisciplinaire HAL, est destinée au dépôt et à la diffusion de documents scientifiques de niveau recherche, publiés ou non, émanant des établissements d'enseignement et de recherche français ou étrangers, des laboratoires publics ou privés. 


\title{
Reversal of Enantioselectivity in the Asymmetric Rhodium- versus Iridium- Catalyzed Hydroboration of meso Substrates
}

\author{
Alejandro Pérez Luna, Martine Bonin, ${ }^{*}$ Laurent Micouin, ${ }^{*}$ and Henri-Philippe Husson \\ Laboratoire de Chimie Thérapeutique, UMR 8638 associée au CNRS et à l'Université René Descartes, Faculté des \\ Sciences Pharmaceutiques et Biologiques, 4 av de l'Observatoire, 75270 Paris cedex 06 (France)
}

RECEIVED DATE (will be automatically inserted after manuscript is accepted)

Since Männig and Nöth first reported the transition metal catalyzed hydroboration, ${ }^{1}$ increasing attention has been paid to the development of this new reaction, especially in the field of asymmetric catalysis. ${ }^{2}$ It was found that chemo-, ${ }^{1}$ regio- ${ }^{3}$ and diastereoselectivities $^{4}$ could be obtained opposite to the uncatalyzed processes. Furthermore, beside the access to enantiopure alcohols or amine derivatives, the transmetalation of the intermediate boronic esters to the corresponding organozinc derivatives considerably broadens the scope of the rhodiumcatalyzed hydroboration. ${ }^{5}$ However, applications of this promising reaction have been restricted to a limited number of substrates; only successful enantioselective hydroboration of styrene and its derivatives (ee $>95 \%$ ), and norbornene in a lesser extent (ee = $84 \%$ ) have been reported. ${ }^{2}$ Despite intensive work, no other metallic substitute for rhodium has been reported to be effective in such an asymmetric transformation. Moreover, improvement of this process is hampered by the understanding of its mechanism which is rather vague. ${ }^{6}$ Herein we report the first example of asymmetric iridium-catalyzed hydroboration. We also bring new insight into the catalytic cycle of this reaction.

Recently, we have developed a straightforward access to polysubstituted diaminocyclopentanes $\mathbf{3}$ based on the desymmetrization of meso bicyclic hydrazines 1 via rhodiumcatalyzed asymmetric hydroboration (Figure 1). ${ }^{7}$

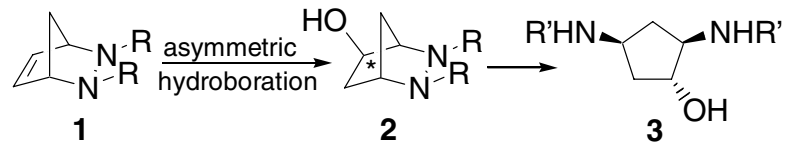

Figure 1. Desymmetrization of meso hydrazines.

Although very few examples of racemic iridium-catalyzed hydroborations have been reported and the reaction with endocyclic alkenes is believed to be very sluggish, ${ }^{8}$ the enhanced reactivity of our substrates compared to norbornene prompted us to test iridium catalysts with this series (Table). Using our previously established hydroboration conditions, we were pleased to see that alcohol 2a could be obtained with $1 \mathrm{~mol} \%$ of $[\mathrm{Ir}(\mathrm{COD}) \mathrm{Cl}]_{2}$ as iridium source (Entry 2 ). A higher chemical yield could be achieved using the same amount of precatalyst loading by increasing the reaction duration (Entry 3). Reaction at room temperature with DIOP as a ligand could afford compound 2a in $40 \%$ yield with $44 \%$ ee (Entry 5 ). This results show for the first time that, despite a lower reactivity, neutral iridium complexes can catalyze asymmetric hydroboration. More interestingly, a complete reversal of enantioselectivity was observed between $\mathrm{Rh}$ and Ir systems. This phenomenon appeared as a general feature since it was observed on all substrates and conditions studied (Scheme 1).
Table. Rhodium-versus iridium catalyzed hydroboration of compound 1a. Influence of ligand.

\begin{tabular}{|c|c|c|c|c|c|}
\hline & $\mathrm{O}$ & $\begin{array}{l}1 \%[\mathrm{M}(\mathrm{COD}) \mathrm{Cl}]_{2} \\
2 \% \mathrm{~L}^{*} \\
2 \text { equiv. CatBH }\end{array}$ & & & \\
\hline & 1a & 2) $\mathrm{H}_{2} \mathrm{O}_{2}$ & & & $2 \mathbf{a}$ \\
\hline entry & $\mathrm{L}^{*}$ & $\begin{array}{l}\text { solvent } \\
\mathrm{T}\left({ }^{\circ} \mathrm{C}\right)(\mathrm{t}[\mathrm{h}])\end{array}$ & $\mathrm{M}$ & $\begin{array}{l}\text { yield } \\
(\%)^{\mathrm{a}}\end{array}$ & $\mathrm{er}^{\mathrm{b}}$ \\
\hline 1 & $(S, S)$-BDPP & DME,-50 (0.5) & $\mathrm{Rh}$ & 91 & $92: 8^{c}$ \\
\hline 2 & $(S, S)$-BDPP & DME,0-RT (0.5) & Ir & 7 & $32: 68$ \\
\hline 3 & $(S, S)$-BDPP & DME,0-RT (7) & Ir & 30 & $34: 66$ \\
\hline 4 & $(S, S)$-DIOP & DME,-50 (0.5) & $\mathrm{Rh}$ & 46 & $23: 77$ \\
\hline 5 & $(S, S)$-DIOP & DME,RT (7) & $\mathrm{Ir}$ & 40 & $72: 28$ \\
\hline 6 & $(R)$-Quinap & DME,-50 (0.5) & $\mathrm{Rh}$ & 11 & $62: 38$ \\
\hline 7 & $(R)$-Quinap & THF,RT (7) & $\mathrm{Ir}$ & 27 & $44: 56$ \\
\hline
\end{tabular}

${ }^{a}$ Yield of analytically pure compound. ${ }^{\mathrm{b}}$ Determined by chiral HPLC. The absolute configuration of the major enantiomer has been established to be $(1 R, 4 R, 5 R)$ (See ref 7$)$.

Scheme 1. Rhodium-versus iridium catalyzed hydroboration (Absolute configurations not determined). ${ }^{a}$

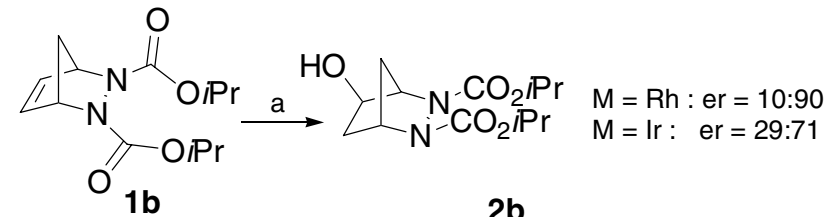

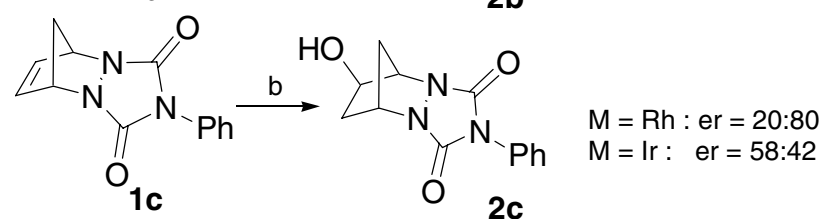

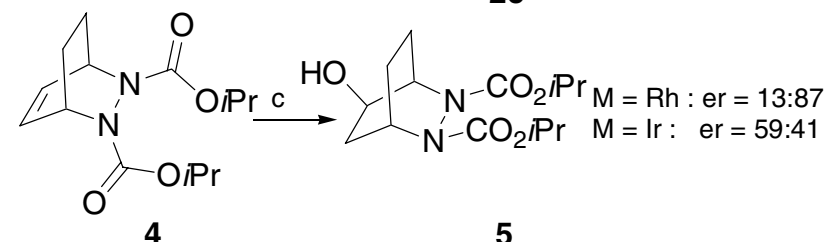

${ }^{a}$ Reagents and conditions: (a) $\mathrm{M}=\mathrm{Rh}, 1 \%[\mathrm{Rh}(\mathrm{COD}) \mathrm{Cl}]_{2}, 2 \%(S, S)-$ BDPP, CatBH (2 equiv.), DME, $-50{ }^{\circ} \mathrm{C}, 0.5$ h,then $\mathrm{H}_{2} \mathrm{O}_{2}, 50 \%$. $\mathrm{M}=\mathrm{Ir}, 1 \%$ $[\operatorname{Ir}(\mathrm{COD}) \mathrm{Cl}]_{2},(S, S)$-BDPP, CatBH (2 equiv.), THF, RT, $7 \mathrm{~h}$, then $\mathrm{H}_{2} \mathrm{O}_{2}$, $26 \%$; (b) $\mathrm{M}=\mathrm{Rh}, 1 \%[\mathrm{Rh}(\mathrm{COD}) \mathrm{Cl}], 2 \%(S, S)-\mathrm{BDPP}, \mathrm{CatBH}$ ( 2 equiv.), DME, $-50{ }^{\circ} \mathrm{C}, 0.5 \mathrm{~h}$, then $\mathrm{H}_{2} \mathrm{O}_{2}, 78 \%$. $\mathrm{M}=\mathrm{Ir}, 1 \%[\operatorname{Ir}(\mathrm{COD}) \mathrm{Cl}]_{2},(S, S)-$ BDPP, CatBH (2 equiv.), THF, RT, 7 h, then $\mathrm{H}_{2} \mathrm{O}_{2}, 9 \%$; (c) $\mathrm{M}=\mathrm{Rh}, 1 \%$ $[\mathrm{Rh}(\mathrm{COD}) \mathrm{Cl}]_{2}, 2 \%(S, S)$-BDPP, CatBH (2 equiv.), DME, $-50{ }^{\circ} \mathrm{C}$ to RT, 7.6 $\mathrm{h}$, then $\mathrm{H}_{2} \mathrm{O}_{2}, 68 \% . \mathrm{M}=\mathrm{Ir}, 10 \%[\operatorname{Ir}(\mathrm{COD}) \mathrm{Cl}]_{2},(S, S)$-BDPP, CatBH $(2$ equiv.), THF, RT, $7 \mathrm{~h}$, then $\mathrm{H}_{2} \mathrm{O}_{2}, 17 \%$. 
To our knowledge, reversal of enantioselectivity in the course of an asymmetric reaction catalyzed by two transition metals having the same $d$ shell electronic configuration is unprecedented. ${ }^{9}$ This observation brings new information on the mechanism of hydroboration. Two main catalytic cycles, based on experimental and theoretical studies, have been proposed (Figure 2). ${ }^{6 b}$ While several authors describe a key step involving a migratory insertion into the metal-H bond, ${ }^{10}$ others favor the migration of a boryl group. ${ }^{11}$ If the insertion step is the determining one in the cycle, these two pathways should lead to opposite regioisomers or, in the case of meso substrates, enantiomers.

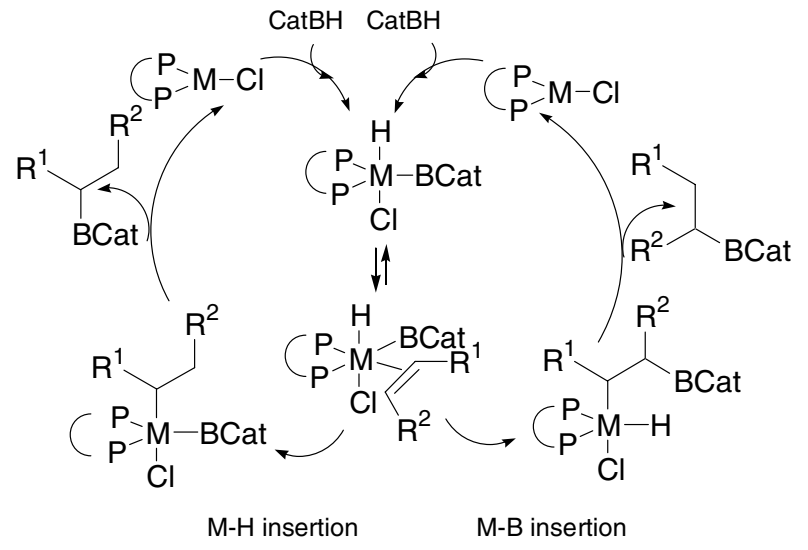

Figure 2. Simplified postulated catalytic cycles for hydroboration

The possible substrate-dependent reversibility of this step complicates the analysis. ${ }^{10}$ In our case, we have a dramatic acceleration of the hydroboration with bicyclic hydrazines compared to the norbornene case. This can be explained by the stabilization of the transition state of the migratory insertion by two $\sigma^{*}$-nitrogen lone pair interactions, and it suggests that this is the first irreversible step in the cycle (Figure 3). ${ }^{12}$
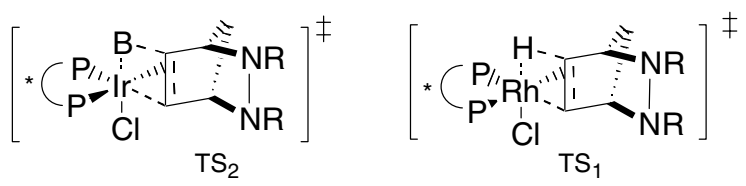

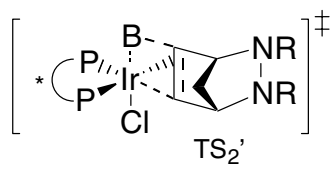

M-B insertion

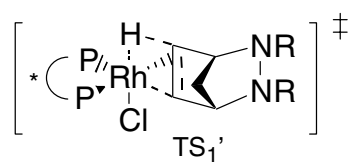

$\mathrm{M}-\mathrm{H}$ insertion
Figure 3. Possible transition states for the migratory insertion steps. Some groups have been omitted for clarity.

Thus, solvent- and ligand- dependent stereoselectivity can be explained by means of the difference in diastereomeric transition states energetic levels $\left(\mathrm{TS}_{1}\right.$ versus $\mathrm{TS}_{1}$, and $\mathrm{TS}_{2}$ versus $\left.\mathrm{TS}_{2}\right)$, and systematic reversal of enantioselectivity (regioselectivity) is likely to be the result of two different insertion pathways ( $\mathrm{TS}_{1}$ versus $\mathrm{TS}_{2}$ and $\mathrm{TS}_{1}$, versus $\mathrm{TS}_{2}$ ). Theoretical studies on bond dissociation energies have shown that insertion into the Ir-Bcat bond is favored by $8 \mathrm{kcal}_{\mathrm{mol}}{ }^{-1}$ over the insertion into the $\mathrm{Ir}-\mathrm{H}$ bond. ${ }^{13} \mathrm{In}$ the case of our substrates, we can propose that this pathway is involved with $[\mathrm{Ir}(\mathrm{COD}) \mathrm{Cl}]_{2}$ and that the use of $[\mathrm{Rh}(\mathrm{COD}) \mathrm{Cl}]_{2}$ involves a key $\mathrm{Rh}-\mathrm{H}$ migratory insertion step.

Finally, chemical yield and enantioselectivity of Ir-based desymmetrization were increased by using commercially available $(R, S)$-Josiphos ligand, leading to alcohols $\mathbf{2 a , b}$ in 46-65 $\%$ yield with ee up to $64 \%$ (Scheme 2 ). These promising results might be improved by a fine electronic tuning of ferrocenyl phosphines or P,N ligands. ${ }^{14}$

Scheme 2. Iridium-catalyzed hydroboration with ferrocenyl phosphine ligand (Absolute configuration : 1S,4S,5S).

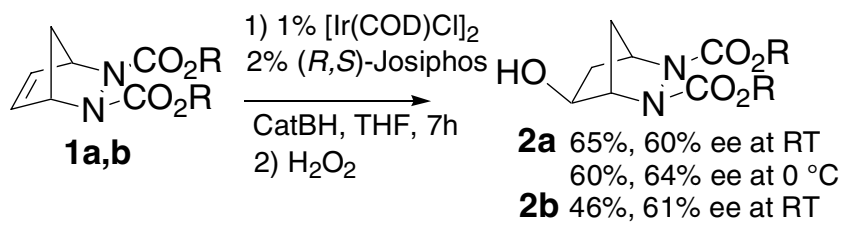

In summary, we have reported the first Ir-catalyzed asymmetric hydroboration with ee and chemical yields up to $64 \%$. We have also shown an unprecedented reversal of enantioselectivity for a catalytic desymmetrization reaction by exchanging two transition metals having the same $d$ shell electronic configuration. These results helped us to show that, at least on our substrates, Rhcatalyzed hydroboration involves a metal- $\mathrm{H}$ insertion and a boryl migration is involved when using an Ir precatalyst. More generally, the use of meso substrates, leading to enantiomers instead of regioisomers, avoids the introduction of thermodynamic bias for regioselectivity, and could be a general tool for the investigation of this kind of problems. ${ }^{15}$

Acknowledgement. We thank CNRS for financial support.

Supporting Information Available : experimental procedures and analytical data for ee determination. This material is free of charge via the Internet at http://pubs.acs.org.

(1) Männig, D.; Nöth, H. Angew. Chem. Int. Ed. Engl. 1985, 24, 878; Angew. Chem. 1985, 97, 854 .

(2) Hayashi, T. in Comprehensive Asymmetric Catalysis, Vol. 1 (Eds.: Jacobsen, E. N.; Pfaltz, A.; Yamamoto, H.), Springer-Verlag, Berlin, 1999, pp 351-364, and references therein.

(3) (a) Evans, D. A.; Fu, G. C.; Hoveyda, A. H. J. Am. Chem. Soc. 1988 110, 6917; (b) Zhang, J.; Lou, B.; Guo, G.; Dai, L. J. Org. Chem. 1991 $56,1670$.

(4) Burgess, K.; Ohlmeyer, M. J. Chem. Rev. 1991, 91, 1179.

(5) Hupe, E.; Calaza, I.; Knochel, P. Tetrahedron Lett. 2001, 42, 8829.

(6) (a) Wadepohl, H. Angew. Chem. Int. Eng. Ed. 1997, 36, 2441; Angew. Chem. 1997, 109, 2547; (b) Beletskaya, I.; Pelter, A. Tetrahedron 1997 $53,4957$.

(7) Pérez Luna, A.; Ceschi, M.-A.; Bonin, M.; Micouin, L.; Husson, H.-P.; Gougeon, S.; Estenne-Bouhtou, G.; Marabout, B.; Sevrin, M.; George, P. J. Org. Chem. 2002, 67, 3522.

(8) (a) Evans, D. A.; Fu, G. C.; Hoveyda, A. H. J. Am. Chem. Soc. 1992, 114, 6671; (b) Westcott, S. A.; Marder, T. B. Organometallics 1993, 12, 975 .

(9) Reversal of enantioselectivity in the asymmetric hydrogenation using $\mathrm{Rh}$-BINAP or Ru-BINAP systems is well documented, but the two catalytic cycles involve completely different reactive intermediates and kinetic profiles: Noyori, R. Asymmetric Catalysis in Organic Synthesis, Wiley-Interscience, New York, 1994.

(10) Experimental studies: Evans, D. A.; Fu, G. C.; Anderson, B. A. J. Am Chem. Soc. 1992, 114, 6679. Theoretical studies: Dorigo, A. E.; von Ragué Schleyer, P. Angew. Chem. Int. Eng. Ed. 1995, 34, 115; Angew. Chem. 1995, 107, 108.

(11) (a) Burgess, K.; van der Donk, W. A.; Westcott, S. A.; Marder, T. B. Baker, R. T.; Calabrese, J. C. J. Am. Chem. Soc. 1992, 114, 9350; (b) Musaev, D. G.; Mebel, A. M.; Morokuma, K. J. Am. Chem. Soc. 1994 $116,10693$.

(12) For similar interactions see : (a) Heymn, M. L.; Snyder, J. P. Tetrahedron Lett. 1973, 30, 2859; (b) Raasch, M. S. J. Org. Chem. 1975, 40, 1975.

(13) Rablen, P. R.; Hartwig, J. F. J. Am. Chem. Soc. 1994, 116, 4121

(14) Schnyder, A.; Togni, A.; Wiesli, U. Organometallics 1997, 16, 255.

(15) Consiglio, G. Chimia, 2001, 55, 809. 


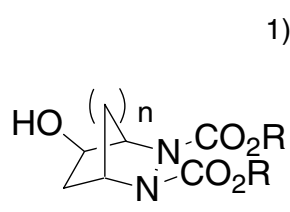

Yields up to $91 \%$ ee up to $84 \%$
1) $1 \%[\mathrm{Rh}(\mathrm{COD}) \mathrm{Cl}]_{2}$ $2 \% \mathrm{~L}^{*}$ eq. CatBH

2) $\mathrm{H}_{2} \mathrm{O}_{2}$

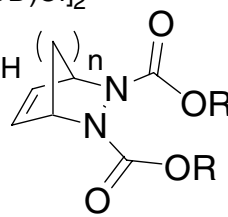

1) $1 \%[\operatorname{Ir}(\mathrm{COD}) \mathrm{Cl}]_{2}$

$2 \% L^{*}$

2 eq. CatBH

$\mathrm{HO} 、 \frac{\mathrm{N}_{\mathrm{N}}^{-}-\mathrm{CO}_{2} \mathrm{R}}{\mathrm{CO}^{\mathrm{n}} \mathrm{R}}$

Yields up to $65 \%$

ee up to $64 \%$

The first example of Ir-catalyzed asymmetric hydroboration with ee and chemical yields up to $64 \%$ is reported. The switch from rhodium to iridium leads systematically to opposite enantiomers in this desymmetrization reaction. 